\title{
Trough concentration of itraconazole and its relationship with efficacy and safety: a systematic review and meta-analysis
}

This article was published in the following Dove Press journal: Infection and Drug Resistance

Jingru Zhang ${ }^{1,2}$

Yiwei Liu'

Xiaolu Nie'

Yuncui Yu'

Jian $\mathrm{Gu}^{3}$

Libo Zhao'

'Clinical Research Center, Beijing Children's Hospital, Capital Medical University, Beijing, China; '2Department of Pharmacy Administration and Clinical Pharmacy, Peking University School of Pharmaceutical Sciences, Beijing, China; ${ }^{3}$ Department of Pharmacy, Peking University People's Hospital, Beijing, China
Correspondence: Libo Zhao Clinical Research Center, Beijing Children's Hospital, Capital Medical University, 56 Nanlishi Road, Xicheng District, Beijing 100045, China

Tel +86 I36 8I 3248 I0 Email lb.zhao@।63.com
Objectives: The optimum trough concentration of itraconazole for clinical response and safty is controversial. The objective of this systematic review and meta-analysis was to determine the optimum trough concentration of itraconazole and evaluate its relationship with efficacy and safety. Methods: We searched PubMed, EMBASE, Web of Science, the Cochrane Library, ClinicalTrials.gov, and three Chinese literature databases (CNKI, WanFang, and CBM). We included observational studies that compared clinical outcomes below or above the trough concentration cut-off value which we set as $0.25,0.5$, and $1.0 \mathrm{mg} / \mathrm{L}$. The efficacy outcomes were rate of successful treatment, rate of prophylaxis failure and invasive fungal infection (IFI)-related mortality. The safety outcomes included incidents of hepatotoxicity and other adverse events. Results: The study included a total of 29 studies involving 2,346 patients. Our meta-analysis showed that compared with itraconazole trough concentrations $\left(\mathrm{C}_{\text {trough }}\right)$ of $\geq 0.25 \mathrm{mg} / \mathrm{L}$, levels of $<0.25 \mathrm{mg} / \mathrm{L}$ significantly increased the incidence of IFI for prophylaxis $(\mathrm{RR}=3.279,95 \%$ confidence interval [CI] 1.73-6.206). Moreover, the success rate of treatment decreased significantly at a cut-off level of $0.5 \mathrm{mg} / \mathrm{L}$ ( $\mathrm{RR}=0.396,95 \%$ CI 0.176-0.889). An itraconazole trough level of 1.0 $\mathrm{mg} / \mathrm{L}$ was associated with hepatotoxicity and other adverse events in a review of many studies.

Conclusion: An itraconazole trough concentration of $0.25 \mathrm{mg} / \mathrm{L}$ should be considered as the lower threshold for prophylaxis, and a target concentration of $0.5 \mathrm{mg} / \mathrm{L}$ should be the lower limit for effective treatment. A trough level of $1.0 \mathrm{mg} / \mathrm{L}$ is associated with increased hepatotoxicity and other adverse events (using High Performance Liquid Chromatography [HPLC]).

Keywords: itraconazole, trough concentration, efficacy, safety, meta-analysis

\section{Introduction}

Fungal infections exact a significant toll on human health and often compromise the clinical outcomes of patients. Prevalently, invasive fungal infection (IFI) is a leading cause of morbidity and mortality among neutropenic patients after intensive chemotherapy or hematopoietic stem cell transplantation, as well as in other immunocompromised populations. ${ }^{1-3}$ Itraconazole is a first-generation triazole antifungal agent with broad-spectrum antifungal activity. In clinical practice, it is commonly used for fungal pathogen infections, such as Candida spp., Cryptococcus neoformans, and Aspergillus $s p p .{ }^{4}$ Itraconazole is often recommended as primary therapy for $\mathrm{IFI}^{5-9}$ and as antifungal prophylaxis in immunocompromised patients. ${ }^{10-12}$ Due to variable and unpredictable oral bioavailability and drug-drug interaction, a satisfactory pharmacokinetics profile cannot be developed with itraconazole in some conditions, making it difficult to determine the optimal dosing regimen. ${ }^{13}$ Hence, therapeutic drug monitoring (TDM), a technique 
that timely and appropriately guides drug dosage modifications, is suggested to optimize the treatment. ${ }^{14}$ Itraconazole trough concentration $\left(\mathrm{C}_{\text {trough }}\right)$ is a strong biomarker for drug exposure, ${ }^{15}$ but most guidelines do not explicitly recommend an optimum trough concentration.

To our knowledge, there have been no randomized controlled trials on the target trough level, so there is no conclusive evidence on the relationship between the optimum trough concentration of itraconazole and its efficacy or safety. However, numerous observational studies have concluded minimum itraconazole level cut-off values, including $0.25,{ }^{16,17} 0.5,{ }^{18,19}$ and $1.0 \mathrm{mg} / \mathrm{L} .{ }^{20} \mathrm{~A} 2014$ guideline from the British society for medical mycology recommended an itraconazole trough concentration of $0.5-1.0 \mathrm{mg} / \mathrm{L}$ to prevent and treat IFI, ${ }^{21}$ which was based on some observational studies $^{22-30}$ and a previous meta-analysis in 2003. ${ }^{31}$ This guideline also proposed an increased incidence of toxicity at higher itraconazole concentrations citing two studies which quantified itraconazole concentrations. ${ }^{32,33}$

Evidence for itraconazole target and critical trough concentrations described in these studies however, remains controversial and has significant limitations. For example, most of the observational studies which contributed to the aforementioned guideline were published more than 20 years ago. These studies often had no clear inclusion/exclusion criteria. Furthermore, the meta-analysis in the guideline ${ }^{31}$ has drawbacks such as lack of standardized outcome definitions among included studies, no detailed itraconazole concentration data, no well-established methodology to perform quality assessment and subgroup analysis to explore the heterogeneity. More importantly, the previous and other metaanalyses ${ }^{34,35}$ were all focused on the evidence of anti-mycoses efficacy or prophylaxis IFIs, rather than on the relationship between itraconazole concentration and efficacy or safety. Therefore, further evaluation of available literature is indicated to provide consistent recommendations for optimizing trough concentration. The objective of this systematic review and meta-analysis was to evaluate the relationship between the reported itraconazole trough concentration and the efficacy/safety of itraconazole.

\section{Methods}

\section{Data sources}

We performed this meta-analysis according to the Cochrane Handbook for Systematic Reviews and the Meta-analysis of Observational Studies in Epidemiology guidelines. ${ }^{36}$ Two reviewers independently searched PubMed, EMBASE, Web of Science, the Cochrane Library, ClinicalTrials.gov, and three Chinese literature databases (CNKI, WanFang, and CBM) from inception until October 2017. We also examined reference lists of retrieved articles and related reviews. We used the search terms "itraconazole" and "concentration". We set no restrictions on language or study design.

\section{Study selection}

Two reviewers (JZ and YL) independently conducted initial screening and assessed titles, abstracts, and citations in greater detail. We included studies if: i) it was an observational study; ii) itraconazole was used for treatment or prophylaxis; iii) TDM was performed; iv) trough concentrations at steady state were reported for included patients; v) sufficient data about rate of treatment success, rate of prophylaxis failure, mortality or incidence of itraconazole-related adverse events (eg, hepatotoxicity) were reported; vi) sample size was $\geq 10$ patients; and (vii) full text of the publication was available. The same reviewers retrieved and assessed the full text of potentially relevant articles using the same criteria. Disagreements were resolved through discussion.

Our exclusion criteria included: i) data came from simulated patients or pharmacokinetic models rather than from real patients; ii) concentrations were not troughs; iii) concentrations were not measured at steady state; iv) concentrations were measured by bioassay.

\section{Cut-off value establishment}

Previous studies ${ }^{37-39}$ showed the MIC90 (MIC at which $90 \%$ of isolates were inhibited) of itraconazole for most yeasts and molds was between 0.25 and $1.0 \mathrm{mg} / \mathrm{L}$. Some studies had shown a target itraconazole trough concentration of $0.25 \mathrm{mg} / \mathrm{L} \cdot{ }^{16,17} \mathrm{~A}$ guideline ${ }^{21}$ and other observational studies $^{18,19}$ suggested $0.5-1.0 \mathrm{mg} / \mathrm{L}$ as itraconazole trough concentration. Patients with $\mathrm{C}_{\text {trough }}$ of $1.0 \mathrm{mg} / \mathrm{L}$ were associated with a high level of clinical response according to Kim et al's 2014 study $^{20}$ and others. ${ }^{40}$ Therefore, we established the stepwise cut-off values for itraconazole efficacy and safety as $0.25,0.5$, and $1.0 \mathrm{mg} / \mathrm{L}$.

\section{Data extraction and outcomes}

The efficacy outcomes included were: IFI-related mortality, treatment success, and prophylaxis failure. Prophylaxis failure was evaluated by the incidence of IFIs, wherein, a high-risk ratio (RR) meant a high treatment success rate or prophylaxis failure rate. The major safety outcomes were hepatotoxicity and occurrence of adverse events. The pooled analysis for treatment success included only treatment studies, while the analysis for prophylaxis failure included only 
prophylaxis studies, and the analysis of side effects included all studies.

Two authors extracted data independently (JZ and YL) and resolved any disagreements by discussion or by a third investigator (XN). We extracted study characteristics, participants' baseline characteristics, methods for measuring itraconazole concentration, type of trough concentration (initial, mean or maximum), cut-off value of itraconazole trough concentration, and pre-specified study outcomes of efficacy and safety from each study under review. If the study already contained a cut-off value, we considered patient groups below the predefined cut-off value as the intervention group, and those above the pre-defined cut-off value as the control. If studies contained no control group, we collected them into a single arm comparison. When individual patient data were available, we used all our pre-defined cut-off values to divide patients into two groups in the same way and extracted the number of events. When the trough concentration was measured multiple times for each patient, we used the mean value of multiple measurements, and we only used the median value when the mean was not available. If neither mean nor median was available, we used the reported trough concentration for that patient in the article. If there were multiple data for the same outcome in an article, we chose the outcome data measured at Day 14 considering itraconazole accumulates slowly and generally reaches concentrations steadily after $7-15$ days of dosing. ${ }^{41,42}$

\section{Quality assessment}

Two independent reviewers (JZ and YL) completed the assessment. We applied the Newcastle-Ottawa Quality Assessment Scale to assess the quality of the included studies with control, ${ }^{43}$ and used a star system (maximum of nine stars) to evaluate the methodological quality of each study. For observational studies without control, we applied a modified version of the Scale that does not evaluate the comparability part, and possible scores ranged from 0 to $6 .{ }^{44}$ Higher scores indicated better quality. We resolved any disagreements between the reviewers through discussion. A third reviewer (XN) was available to settle any disputes.

\section{Data analysis}

We performed all analyses using the Open Meta-Analyst software (Tufts Medical Center, Boston, MA, USA). The $I^{2}$ statistic was used to assess heterogeneity among studies. $I^{2}$ values over $25 \%, 50 \%$, and $75 \%$ represented low, moderate, and considerable heterogeneity, respectively. ${ }^{45}$ To assess variations between studies in addition to sampling error within studies, we selected the fixed-effects model if $I^{2}<50 \%$, and the random-effects model when $R^{2} \geq 50 \%$. The DerSimonian-Laird or the Mantel-Haenszel method was used to calculate the PR or RR and 95\% confidence interval (CI) for each study. The $95 \%$ CI of outcome among distinct groups did not overlap, showing that outcomes were statistically significant. $P<0.05$ was considered statistically significant.

\section{Subgroup analyses}

To explore the heterogeneity among different studies, we performed a subgroup analysis when more than two studies were included in the analysis of each cut-off level. For the treatment outcome, studies were stratified by: i) studies reporting single drug therapy compared with studies including patients on combination therapy (at least some patients on combination therapy); ii) studies located in Asian countries compared with in non-Asian countries. For the prophylaxis outcome, studies were stratified by location in Asian countries or European countries, or in America and Australia.

\section{Sensitivity analysis}

We performed sensitivity analysis to examine whether a single study substantially influenced the core results. We excluded each study and evaluated its effect on the summary estimates and heterogeneity of the main analysis, then reported the results for sensitivity analysis if the conclusions differed.

\section{Results}

\section{Literature searches and study inclusion}

The literature selection process is summarized in Figure 1. A total of 7,007 articles were initially identified. After initial screening, 68 full-text, potentially relevant articles were selected, 39 studies were excluded owing to inadequate clinical outcomes data, concentration was not a trough or at steady-state, or itraconazole alone, or measured by bioassay, among other reasons. Ultimately, 29 articles involving 2,346 patients were included for meta-analysis. ${ }^{16-19,22-24,30,46-65}$

\section{Study characteristics}

A summary of descriptions of included studies is reported in Table 1. Of these 29 studies, seven studies used itraconazole for treatment ${ }^{30,46-51}$ and 22 studies used itraconazole for prophylaxis. ${ }^{16-19,22-24,52-65}$ Fourteen were conducted in European countries, six were in Japan, ${ }^{16,48,50,53,55,63}$ three were in China, ${ }^{61,64,65}$ three were in America, ${ }^{23,57,59}$ two in Australia, ${ }^{18,62}$ and one in South Korea. ${ }^{20}$ Among these, two studies were conducted in children who used itraconazole for prophylaxis. ${ }^{54,56}$ 


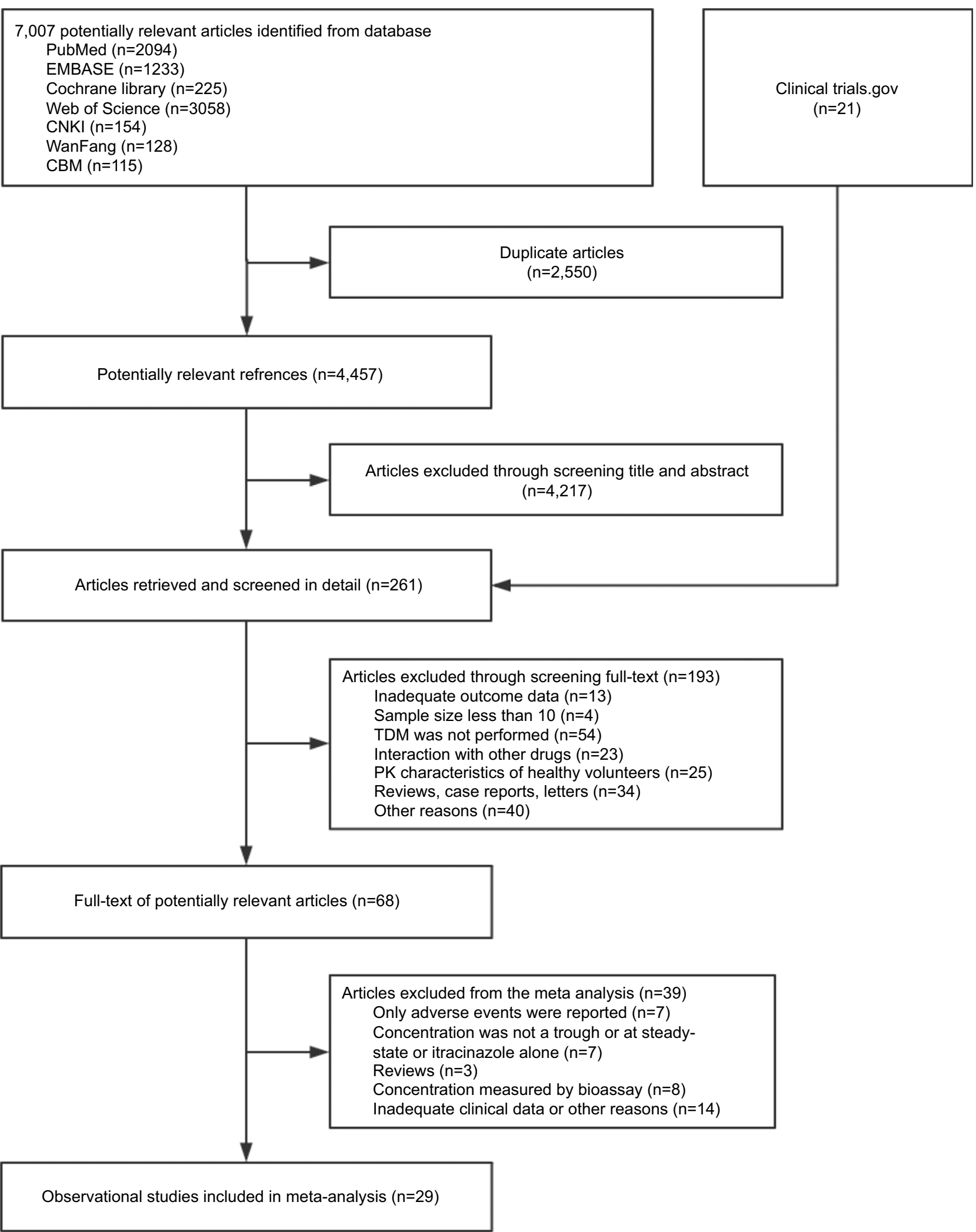

Figure I Flow chart of study selection.

Abbreviations: TDM, therapeutic drug monitoring; PK, pharmacokinetic. 
Table I Characteristics of included studies

\begin{tabular}{|c|c|c|c|c|c|c|c|c|c|}
\hline \multicolumn{10}{|c|}{ Itraconazole used for treatment } \\
\hline $\begin{array}{l}\text { First } \\
\text { author } \\
\text { year }\end{array}$ & Country & $\begin{array}{l}\text { Study } \\
\text { design }\end{array}$ & $\begin{array}{l}\text { Sample size } \\
\text { (male/female) }\end{array}$ & Age $(y)^{a}$ & $\begin{array}{l}\text { Main Disease } \\
\text { (\%) }\end{array}$ & $\begin{array}{l}\text { Type of } \\
\text { fungal } \\
\text { infection } \\
\text { (n) }\end{array}$ & $\begin{array}{l}\text { Main site } \\
\text { of infection }\end{array}$ & Duration & $\begin{array}{l}\text { Combo } \\
\text { therapy }\end{array}$ \\
\hline $\begin{array}{l}\text { Cross et al } \\
2000^{30}\end{array}$ & UK & $\begin{array}{l}\text { prospective } \\
\text { study }\end{array}$ & $40(9 / 31)$ & $62(29-8 I)$ & $\begin{array}{l}\text { Candida- } \\
\text { associated } \\
\text { denture } \\
\text { stomatitis }\end{array}$ & proven (36) & mouth & 15 days & no \\
\hline $\begin{array}{l}\text { Lebeau et al } \\
1994^{46}\end{array}$ & France & $\begin{array}{l}\text { retrospective } \\
\text { study }\end{array}$ & $16(9 / 7)$ & $48(8-86)$ & $\begin{array}{l}\text { hematological } \\
\text { disorder ( } 38) \text {; } \\
\text { cystic fibrosis } \\
\text { (19); } \\
\text { Hodgkin's } \\
\text { disease (19) }\end{array}$ & proven (16) & lung & $\begin{array}{l}14-488 \\
\text { days }\end{array}$ & yes \\
\hline $\begin{array}{l}\text { bHavu et al } \\
1999^{47}\end{array}$ & Finland & $\begin{array}{l}\text { prospective } \\
\text { study }\end{array}$ & 129 & NR & onychomycosis & NR & $\begin{array}{l}\text { Fingernails, } \\
\text { toenails }\end{array}$ & 3 months & no \\
\hline $\begin{array}{l}\text { Matsumoto } \\
\text { et al } 1999^{48}\end{array}$ & Japan & $\begin{array}{l}\text { prospective } \\
\text { study }\end{array}$ & $23(13 / 10)$ & $58.3 \pm 10.8$ & onychomycosis & $\begin{array}{l}\text { Proven (15) } \\
\text { probable (8) }\end{array}$ & $\begin{array}{l}\text { Fingernails, } \\
\text { toenails }\end{array}$ & NR & no \\
\hline $\begin{array}{l}\text { Caillot } \\
2003^{49}\end{array}$ & France & $\begin{array}{l}\text { prospective } \\
\text { study }\end{array}$ & $21(13 / 8)$ & $48(25-78)$ & $\begin{array}{l}\text { hematological } \\
\text { malignancy }\end{array}$ & proven (2I) & lung & 14 weeks & yes \\
\hline $\begin{array}{l}\text { Yoshida et al } \\
2012^{50}\end{array}$ & Japan & $\begin{array}{l}\text { prospective } \\
\text { study }\end{array}$ & $24(5 / 9)$ & $64(39-89)$ & $\begin{array}{l}\text { respiratory } \\
\text { disease }\end{array}$ & proven (64) & $\begin{array}{l}\text { respiratory } \\
\text { field, lung }\end{array}$ & $\begin{array}{l}51.7 \pm 34.0 \\
\text { days }\end{array}$ & no \\
\hline $\begin{array}{l}\text { Caillot et al } \\
\left.200\right|^{51}\end{array}$ & Belgium & $\begin{array}{l}\text { prospective } \\
\text { study }\end{array}$ & $3 I(20 / I I)$ & $48(25-78)$ & $\begin{array}{l}\text { hematologic } \\
\text { malignancies } \\
(87)\end{array}$ & proven $(3 \mathrm{I})$ & lung & $\begin{array}{l}14(4-28) \\
\text { days }\end{array}$ & no \\
\hline \multicolumn{10}{|c|}{ Itraconazole used for prophylaxis } \\
\hline $\begin{array}{l}\text { First } \\
\text { author } \\
\text { year }\end{array}$ & Country & $\begin{array}{l}\text { Study } \\
\text { design }\end{array}$ & $\begin{array}{l}\text { Sample size } \\
\text { (male/female) }\end{array}$ & Age (y) & $\begin{array}{l}\text { Main Disease } \\
\%\end{array}$ & $\begin{array}{l}\text { Duration } \\
\text { (d) }\end{array}$ & Follow-up (d) & & \\
\hline $\begin{array}{l}\text { Myoken et al } \\
2002^{16}\end{array}$ & Japan & $\begin{array}{l}\text { retrospective } \\
\text { study }\end{array}$ & 16 & NR & acute leukemia & 57 months & 10 & & \\
\hline $\begin{array}{l}\text { Tricot et al } \\
1987^{23}\end{array}$ & USA & $\begin{array}{l}\text { prospective } \\
\text { study }\end{array}$ & $45(27 / / 8)$ & $45(9-78)$ & $\begin{array}{l}\text { hematologic } \\
\text { diseases }\end{array}$ & NR & NR & & \\
\hline $\begin{array}{l}\text { Boogaerts } \\
\text { et al } 1989^{22}\end{array}$ & Belgium & $\begin{array}{l}\text { prospective } \\
\text { study }\end{array}$ & $72(40 / 32)$ & 45 (9-78) & $\begin{array}{l}\text { Hematological } \\
\text { malignancies }\end{array}$ & 42 & NR & & \\
\hline $\begin{array}{l}\text { Morgenstern } \\
\text { et al } 1999^{52}\end{array}$ & UK & $\begin{array}{l}\text { prospective } \\
\text { study }\end{array}$ & $445(276 / 169)$ & mean:44 5 & $\begin{array}{l}\text { hematological } \\
\text { malignancies }\end{array}$ & 90 & 30 & & \\
\hline $\begin{array}{l}\text { Harousseau } \\
\text { et al } 2000^{17}\end{array}$ & $\begin{array}{l}\text { European } \\
\text { countries }\end{array}$ & $\begin{array}{l}\text { prospective } \\
\text { study }\end{array}$ & $28 I(167 / 114)$ & $48(15-75)$ & $\begin{array}{l}\text { Hematological } \\
\text { Malignancy }\end{array}$ & $19(I-56)$ & NR & & \\
\hline $\begin{array}{l}\text { Kageyama } \\
\text { et al 199953 }\end{array}$ & Japan & $\begin{array}{l}\text { prospective } \\
\text { study }\end{array}$ & $14(8 / 6)$ & $50(25-79)$ & acute leukemia & (I4-NR) & NR & & \\
\hline $\begin{array}{l}\text { Brett et al } \\
2013^{18}\end{array}$ & Australia & $\begin{array}{l}\text { Retrospective } \\
\text { study }\end{array}$ & $57(30 / 27)$ & NR & $\begin{array}{l}\text { Heart and Lung } \\
\text { Transplantation }\end{array}$ & $(30-135)$ & NR & & \\
\hline $\begin{array}{l}\text { Ceesay et al } \\
2016^{19}\end{array}$ & UK & $\begin{array}{l}\text { prospective } \\
\text { study }\end{array}$ & $53(33 / 20)$ & $52(23-68)$ & $\begin{array}{l}\text { hematological } \\
\text { malignancies }\end{array}$ & NR & NR & & \\
\hline $\begin{array}{l}\text { cSchmitt } \\
\text { et al } 200 I^{54}\end{array}$ & France & $\begin{array}{l}\text { prospective } \\
\text { study }\end{array}$ & $17(10 / 7)$ & - & $\begin{array}{l}\text { Hematologic } \\
\text { Malignancy (7I) }\end{array}$ & NR & NR & & \\
\hline $\begin{array}{l}\text { Kanda et al } \\
1998^{55}\end{array}$ & Japan & $\begin{array}{l}\text { prospective } \\
\text { study }\end{array}$ & 18 & NR & $\begin{array}{l}\text { hematological } \\
\text { malignancies }\end{array}$ & NR & NR & & \\
\hline $\begin{array}{l}\text { Glasmacher } \\
\text { et al 199924 }\end{array}$ & Germany & $\begin{array}{l}\text { Retrospective } \\
\text { study }\end{array}$ & 150 & $54(4 I-64)$ & $\begin{array}{l}\text { hematological } \\
\text { malignancies }\end{array}$ & 21 & NR & & \\
\hline $\begin{array}{l}\text { Simon et al } \\
2007^{56}\end{array}$ & Germany & $\begin{array}{l}\text { prospective } \\
\text { study }\end{array}$ & $39(20 / 19)$ & $6.4(0.7-11,5)$ & $\begin{array}{l}\text { hematological } \\
\text { malignancies }\end{array}$ & $27(6-246)$ & NR & & \\
\hline $\begin{array}{l}\text { Marr et al } \\
2004^{57}\end{array}$ & USA & $\begin{array}{l}\text { prospective } \\
\text { study }\end{array}$ & I5I (75/76) & NR & $\begin{array}{l}\text { allogeneic stem } \\
\text { cell transplants }\end{array}$ & 89 & 708 & & \\
\hline $\begin{array}{l}\text { Boogaerts } \\
\text { et al } 200 I^{58}\end{array}$ & Belgium & $\begin{array}{l}\text { prospective } \\
\text { study }\end{array}$ & $17(9 / 8)$ & $41(19-60)$ & $\begin{array}{l}\text { Hematologic } \\
\text { Malignancy }\end{array}$ & 21 & NR & & \\
\hline
\end{tabular}


Table I (Continued)

\begin{tabular}{|c|c|c|c|c|c|c|c|}
\hline \multicolumn{8}{|c|}{ Itraconazole used for prophylaxis } \\
\hline $\begin{array}{l}\text { First } \\
\text { author } \\
\text { year }\end{array}$ & Country & $\begin{array}{l}\text { Study } \\
\text { design }\end{array}$ & $\begin{array}{l}\text { Sample size } \\
\text { (male/female) }\end{array}$ & Age (y) & $\begin{array}{l}\text { Main Disease } \\
\%\end{array}$ & $\begin{array}{l}\text { Duration } \\
\text { (d) }\end{array}$ & Follow-up (d) \\
\hline $\begin{array}{l}\text { Winston } \\
\text { et al } 2002^{59}\end{array}$ & USA & $\begin{array}{l}\text { prospective } \\
\text { study }\end{array}$ & $97(5 \mathrm{I} / 46)$ & $53(24-72)$ & liver transplant & 70 & ly \\
\hline $\begin{array}{l}\text { Glasmacher } \\
\text { et al } 1998^{60}\end{array}$ & Germany & $\begin{array}{l}\text { Retrospective } \\
\text { study }\end{array}$ & $47(27 / 20)$ & $57.0(19-84)$ & $\begin{array}{l}\text { Acute } \\
\text { leukaemia }\end{array}$ & NR & NR \\
\hline $\begin{array}{l}\text { 'Lin et al } \\
2014^{61}\end{array}$ & China & $\begin{array}{l}\text { prospective } \\
\text { study }\end{array}$ & $|2|(76 / 45)$ & - & $\begin{array}{l}\text { Allogeneic } \\
\text { HSCT }\end{array}$ & - & $180(8-180)$ \\
\hline $\begin{array}{l}\text { Kim et al } \\
2014^{20}\end{array}$ & South Korea & $\begin{array}{l}\text { prospective } \\
\text { study }\end{array}$ & I8I (98/83) & $54(20-83)$ & $\begin{array}{l}\text { hematological } \\
\text { malignancies }\end{array}$ & 14 & NR \\
\hline $\begin{array}{l}\text { Lindsay et al } \\
2017^{62}\end{array}$ & Australia & $\begin{array}{l}\text { prospective } \\
\text { cohort study }\end{array}$ & $57(36 / 2 I)$ & $\begin{array}{l}\operatorname{mean} 51.8 \\
(18-76)\end{array}$ & HSCT (8I ) & - & - \\
\hline $\begin{array}{l}\text { Liu et al } \\
2015^{64}\end{array}$ & China & $\begin{array}{l}\text { prospective } \\
\text { study }\end{array}$ & $35(2 \mid / / 4)$ & $37(14-64)$ & Hemopathy & $(\mathrm{NR}-180)$ & NR \\
\hline $\begin{array}{l}\text { Toubai et al } \\
2005^{63}\end{array}$ & Japan & $\begin{array}{l}\text { prospective } \\
\text { study }\end{array}$ & $37(2|/| 6)$ & $46(16-77)$ & $\begin{array}{l}\text { hematological } \\
\text { malignancies }\end{array}$ & - & - \\
\hline $\begin{array}{l}\text { Liu et al } \\
2013^{64}\end{array}$ & China & $\begin{array}{l}\text { prospective } \\
\text { study }\end{array}$ & $112(68 / 44)$ & $37(18-64)$ & $\begin{array}{l}\text { acute myeloid } \\
\text { leukemia }\end{array}$ & NR & NR \\
\hline
\end{tabular}

Notes: NR, not reported; HSCT, hematopoietic stem cell transplantation. age was represented as median (interquartile range) or mean \pm SD. ${ }^{\mathrm{b}} \mathrm{Continuous} \mathrm{treatment} \mathrm{with}$ itraconazole $200 \mathrm{mg}$ once daily for 3 months were considered for this articl. 'Ten patients in group I (aged I.7 to 4.9 years; median, I year); and seven in group 2 (aged 6.2 to 14.3 years; median, 10 years). ${ }^{\mathrm{d}}$ The median age was 27.70 (12.2-52.9) years in the long-term arm and 23.60 (12.5-55.6) years in the short-term arm. The median duration of administration was 90 days (range, 4-96 days) in the long-term arm and 32 days (range, 9-35 days) in the short-term arm.

Ten studies used serum samples, ${ }^{16,20,24,30,52,57,60-62,64}$ while the other 15 used plasma samples. ${ }^{17,18,20,22,23,46-49,51,55,56,58,59,63}$ The remainder did not report whether serum or plasma sample was used. All the included studies measured itraconazole concentrations by HPLC.

\section{Evaluation of efficacy}

Table 2 displays a summary of outcomes for each study, and Tables 3-7 exhibit summaries of meta-analysis and subgroup analysis and sensitivity analysis for efficacy. Figures 2 and 3 and Figures S1-S10 show forest plots.

Our meta-analysis demonstrated there were no significant differences at all cut-off values for efficacy (without control arm) (Table 3). In comparing efficacy, including studies with control arm, we found a significant difference at the cut-off level of $0.25 \mathrm{mg} / \mathrm{L}$ for incidence of IFI $(\mathrm{RR}=3.279,95 \% \mathrm{CI}$ 1.73-6.206) (Table 4 and Figure 2). For treatment success, our meta-analysis based on two studies, showed that the success rate decreased at a cut-off level of $0.5 \mathrm{mg} / \mathrm{L}$ (RR $=0.396,95 \%$ CI $0.176-0.889)$ (Table 4, Figure 3 ). Only one study contributed data for IFI-related mortality so we were unable to pool the data. ${ }^{60}$

Subgroup analysis showed that the rate of prophylaxis failure significantly increased at a cut-off level of $<0.25 \mathrm{mg} / \mathrm{L}$ in USA + Australia subgroup patients $(\mathrm{PR}=0.524,95 \% \mathrm{CI}$ $0.310-0.737)$ compared with other concentration regimens. There were no significant differences at other cut-off levels (Tables 5-7).

\section{Sensitivity analysis}

We identified moderate to considerable inter-study heterogeneity during some of the meta-analyses, so we used a random-effects model when $I^{2} \geq 50 \%$ and the source of heterogeneity assessed in subgroup analysis according to combination therapy and study location (Tables 5-7). The heterogeneity we observed may also be due to diseases, itraconazole dose, sample size, age, and/or the criteria used for assessment - these factors led us to also conduct sensitivity analysis. The trial by Caillot et al in 2001 with relatively small sample size or including complete and partial responders for outcome was omitted and analyzed again to test the stability of the final pooled results. ${ }^{51}$ The results showed that, in $\geq 0.25 \mathrm{mg} / \mathrm{L}$ and $\geq 1.0 \mathrm{mg} / \mathrm{L}, I^{2}$ was significantly decreased to less than $50 \%$. When we removed another study with relatively small sample size or proven and possible IFI, there was a decline to less than $50 \%$ of $I^{2}$ in $<0.5 \mathrm{mg} / \mathrm{L}$ range group. ${ }^{63}$ Though $I^{2}$ decreased, the $95 \%$ CI did not change significantly, demonstrating that the metaanalysis results were robust. Sensitivity analysis results were summarized in Tables S1 and S2.

\section{Evaluation of safety}

Due to different reported safety outcomes and variable definitions of hepatotoxicity, we could not pool the data to perform a meta-analysis. In general, itraconazole was well tolerated in most patients.

Regarding treatment, Miller ${ }^{66}$ reported that two of 13 patients with itraconazole $\mathrm{C}_{\text {trough }}<0.25 \mathrm{mg} / \mathrm{L}$ had adverse 
Table 2 Outcomes and results of included studies

\begin{tabular}{|c|c|c|c|c|}
\hline \multicolumn{5}{|c|}{ Itraconazole used for treatment } \\
\hline First author year & $\begin{array}{l}\text { Type of } \\
\mathrm{C}_{\text {trough }}\end{array}$ & Cut-off value & Reported outcome & Definition of treatment success \\
\hline Cross et al $2000^{30}$ & initial & all & treatment success & $\begin{array}{l}\text { mycologically cured patients and non-cured } \\
\text { patients }\end{array}$ \\
\hline Lebeau et al $1994^{46}$ & mean & $0.5, I .0$ & $\begin{array}{l}\text { treatment success } \\
\text { liver function disorders }\end{array}$ & respond to therapy (recovery or improvement) \\
\hline Havu et al 199947 & mean & $\geq 0.25,<0.5,<1.0$ & treatment success & responders and non-responders \\
\hline $\begin{array}{l}\text { Matsumoto et al } \\
1999^{48}\end{array}$ & mean & $<0.25,<0.5,>1.0$ & treatment success adverse events & significant improvement and improvement \\
\hline Caillot $2003^{49}$ & mean & $\geq 0.25, \geq 0.5,<1.0$ & treatment success adverse events & complete or partial response \\
\hline Yoshida et al $2012^{50}$ & mean & $\geq 0.25, \geq 0.5, \geq 1.0$ & $\begin{array}{l}\text { treatment success liver dysfunction and } \\
\text { other adverse events }\end{array}$ & Improvement (response) \\
\hline Caillot et al $2001^{51}$ & median & $\geq 0.25, \geq 0.5, \geq 1.0$ & $\begin{array}{l}\text { treatment success } \\
\text { adverse events }\end{array}$ & complete or partial response \\
\hline \multicolumn{5}{|c|}{ Itraconazole used for prophylaxis } \\
\hline First author year & $\begin{array}{l}\text { Type of } \\
\mathrm{C}_{\text {trough }}\end{array}$ & Cut-off value & Reported outcome & Definition of occurrence of IFI \\
\hline Myoken et al $2002^{16}$ & mean & 0.25 & occurrence of IFI & Positive cultures \\
\hline Tricot et al $1987^{23}$ & mean & 0.25 & occurrence of IFI & Positive cultures \\
\hline Boogaerts et al $1989^{22}$ & mean & 0.25 & Incidence of proven and suspected IFI & Positive cultures \\
\hline $\begin{array}{l}\text { Morgenstern et al } \\
1999^{52}\end{array}$ & mean & $0.25,0.5$ & proven fungal infections & $\begin{array}{l}\text { clinical/radiological and mycological evidence, } \\
\text { positive cultures }\end{array}$ \\
\hline $\begin{array}{l}\text { Harousseau et al } \\
2000^{17}\end{array}$ & mean & 0.25 & $\begin{array}{l}\text { occurrence of IFI } \\
\text { adverse events }\end{array}$ & positive cultures \\
\hline Kageyama et al $1999^{53}$ & initial & all & occurrence of IFI & NR \\
\hline Brett et al $2013^{18}$ & initial & 0.5 & breakthrough IFI & EORTC/MSG, positive cultures \\
\hline Ceesay et al $2016^{19}$ & median & 0.5 & occurrence of IFI & EORTC/MSG, proven and probable IFI \\
\hline${ }^{\mathrm{c} S c h m i t t}$ et al $200 \mathrm{I}^{54}$ & mean & 1.0 & occurrence of IFI & NR \\
\hline Kanda et al $1998^{55}$ & mean & $\geq 0.25,<0.5,<1.0$ & pulmonary aspergillus infection & $\begin{array}{l}\text { diagnosed by a computed tomography scan of } \\
\text { the chest and by the detection of aspergillus } \\
\text { antigen. }\end{array}$ \\
\hline $\begin{array}{l}\text { Glasmacher et al } \\
1999^{24}\end{array}$ & initial & $\geq 0.25, \geq 0.5,<1.0$ & occurrence of IFI & $\begin{array}{l}\text { clinical or radiological signs of infection, positive } \\
\text { culture, include proven or highly suspected } \\
\text { invasive fungal infections }\end{array}$ \\
\hline Simon et al $2007^{56}$ & mean & $\geq 0.25, \geq 0.5,<1.0$ & breakthrough IFI & $N R$ \\
\hline Marr et al $2004^{57}$ & median & $\geq 0.25, \geq 0.5,<1.0$ & occurrence of IFI & EORTC/MSG, proven and probable IFI \\
\hline Boogaerts et al $200 I^{58}$ & mean & $\geq 0.25, \geq 0.5,<1.0$ & $\begin{array}{l}\text { occurrence of IFI } \\
\text { abnormal AST/ALT value }\end{array}$ & NR \\
\hline Winston et al $2002^{59}$ & mean & $\geq 0.25,<0.5,<1.0$ & $\begin{array}{l}\text { occurrence of IFI } \\
\text { liver function disorders }\end{array}$ & EORTC/MSG, positive cultures, proven \\
\hline $\begin{array}{l}\text { Glasmacher et al } \\
1998^{60}\end{array}$ & median & $\geq 0.25, \geq 0.5,<1.0$ & $\begin{array}{l}\text { IFI-related mortality } \\
\text { occurrence of IFI hepatotoxicity and } \\
\text { other adverse events }\end{array}$ & $\begin{array}{l}\text { proven invasive fungal infection } \\
\text { (I) Histological and/or microbiological proof } \\
\text { (2) Radiological evidence and microbiological } \\
\text { isolation of a fungus }\end{array}$ \\
\hline d Lin et al $2014^{61}$ & mean & $\geq 0.25, \geq 0.5,<1.0$ & $\begin{array}{l}\text { Breakthrough IFI liver dysfunction and } \\
\text { other adverse events }\end{array}$ & $\begin{array}{l}\text { EORTC/MSG, Breakthrough IFI (proven, } \\
\text { probable, and possible). }\end{array}$ \\
\hline Kim et al $2014^{20}$ & mean & $\geq 0.25, \geq 0.5, \geq 1.0$ & $\begin{array}{l}\text { Breakthrough IFI hepatotoxicity and other } \\
\text { adverse events }\end{array}$ & $\begin{array}{l}\text { Breakthrough fungal infections, probable or } \\
\text { proven }\end{array}$ \\
\hline Lindsay et al $2017^{62}$ & mean & $\geq 0.25, \geq 0.5, \geq 1.0$ & occurrence of IFI liver function disorders & EORTC/MSG, Possible or probable IFI \\
\hline Liu et al $2015^{64}$ & mean & $\geq 0.25, \geq 0.5,<1.0$ & $\begin{array}{l}\text { occurrence of IFI elevated } \\
\text { aminotransferase value }\end{array}$ & NR \\
\hline Toubai et al $2005^{63}$ & mean & $\geq 0.25, \geq 0.5,<1.0$ & occurrence of IFI adverse events & $\begin{array}{l}\text { clinical symptoms and positive cultures (proven } \\
\text { and possible) }\end{array}$ \\
\hline Liu et al $2013^{64}$ & mean & $\geq 0.25, \geq 0.5,<1.0$ & occurrence of IFI adverse events & $\begin{array}{l}\text { confirmed diagnosis, clinical diagnosis, } \\
\text { suspected diagnosis }\end{array}$ \\
\hline
\end{tabular}

Abbrevations: $C_{\text {trough }}$, trough concentration; NR, not reported; EORTC-MSG, European Organization for Research and Treatment of Cancer/lnvasive Fungal Infections Cooperative Group and the National Institute of Allergy and Infectious Diseases Mycoses Study Group. 
events grade 3 or 4 related to study treatment. Matsumoto et $\mathrm{al}^{48}$ found patients with $\mathrm{C}_{\text {trough }}<0.25 \mathrm{mg} / \mathrm{L}$ experienced mild diarrhea (one case), mild drug eruption (one case), and abnormal GOT and GPT (one case). Lebeau et $\mathrm{al}^{46}$ reported that two patients presented with liver function disorders with concentration $0.25-0.5 \mathrm{mg} / \mathrm{L}$ and $0.5-1.0 \mathrm{mg} / \mathrm{L}$, respectively. Nine patients $(43 \%)$ with $\mathrm{C}_{\text {trough }} 0.5-1.0 \mathrm{mg} / \mathrm{L}$ experienced severe adverse events in Caillot's study. ${ }^{49}$ Among these nine cases, there was only one severe reaction definitely related to itraconazole treatment. In a study including a concentration more than $1.0 \mathrm{mg} / \mathrm{L}$, researchers observed adverse events such as liver dysfunction in four patients and heart failure in five of a total of 24 patients in Yoshida et al's study. ${ }^{50}$ In another trial, ${ }^{51}$ only two events were considered definitely related to the treatment: rash in one patient and rigors during drug administration in another. Thirteen patients $(42 \%)$ experienced

Table 3 Summary of meta-analysis for efficacy (without control arm)

\begin{tabular}{|c|c|c|c|c|}
\hline $\begin{array}{l}\text { Cut-off } \\
\text { value } \\
\text { (mg/L) }\end{array}$ & PR (95\% Cl) & $\begin{array}{l}\text { Number } \\
\text { of studies }\end{array}$ & $\begin{array}{l}\text { Number of } \\
\text { participants }\end{array}$ & $12 \%$ \\
\hline \multicolumn{5}{|c|}{ Rate of treatment success } \\
\hline$<0.25$ & $0.498(-0.204,1.200)$ & 2 & 22 & 93.32 \\
\hline$\geq 0.25$ & $0.527(0.402,0.652)$ & 6 & 154 & 61.68 \\
\hline$<0.5$ & $0.549(0.209,0.888)$ & 4 & 72 & 91.06 \\
\hline$\geq 0.5$ & $0.552(0.373,0.730)$ & 5 & 104 & 73.96 \\
\hline$<1.0$ & $0.632(0.478,0.787)$ & 5 & 108 & 67.24 \\
\hline$\geq 1.0$ & $0.480(0.304,0.657)$ & 4 & 68 & 52.43 \\
\hline \multicolumn{5}{|c|}{ Incidence of IFI } \\
\hline$<0.25$ & $0.183(0.047,0.319)$ & 6 & 149 & 88.81 \\
\hline$\geq 0.25$ & $0.081(0.053,0.109)$ & 19 & $\mathrm{I}, 726$ & 85.9 \\
\hline$<0.5$ & $0.126(0.052,0.199)$ & 7 & 251 & 71.28 \\
\hline$\geq 0.5$ & $0.077(0.044,0.110)$ & 15 & 1,317 & 85.74 \\
\hline$<1.0$ & $0.101(0.061,0.140)$ & 13 & 1,089 & 79.17 \\
\hline$\geq 1.0$ & $0.047(0.021,0.074)$ & 4 & 245 & 0 \\
\hline
\end{tabular}

Abbreviations: $\mathrm{Cl}$, confidence interval; IFI, invasive fungal infection adverse events possibly related to treatment. Together, these numbers are substantial in terms of adverse events results.

Regarding prophylaxis, of 97 patients on itraconazole with $\mathrm{C}_{\text {trough }} 0.25-0.5 \mathrm{mg} / \mathrm{L}$, three patients had abnormal liver function tests possibly related to itraconazole, but no patients were removed from the study because of concerns about hepatotoxicity from itraconazole according to Winston and Busuttil. ${ }^{59}$ In addition, we discovered from Toubai et al's study, ${ }^{63}$ that there were no other obvious side effects caused by prophylactic itraconazole administration. For $\mathrm{C}_{\text {trough }} 0.5-1.0$ $\mathrm{mg} / \mathrm{L}$, Boogaerts et $\mathrm{al}^{58}$ reported three cases of abnormal rise in AST/ALT levels in 17 patients. Serious adverse events were reported in 26 (9\%) patients in Harousseau et al's study. ${ }^{17}$ Glasmacher et al, ${ }^{60}$ in their study, claimed that there were no severe adverse effects (necessitating an interruption of prophylaxis) clearly attributable to itraconazole, especially no severe hepatotoxicity events. Lin et al's study ${ }^{61}$ showed that drug-related adverse events occurred in $19(15.7 \%)$ of the patients involved, including 15 with gastrointestinal disorders (12.4\%), two with abnormal liver function (1.65\%), one with hypokalemia (1/121), and one with hydrothorax $(0.8 \%)$. In Liu's study there were 16 patients who withdrew from the study due to adverse reactions, including three cases of elevated aminotransferase. ${ }^{65}$ Adverse events were observed in as many as 42 patients $(14.1 \%)$ in Liu et al's study (transaminase elevation in two patients, drug withdrawal in 16 , heart dysfunction in one). ${ }^{64}$ For $\mathrm{C}_{\text {trough }} \geq 1.0 \mathrm{mg} / \mathrm{L}$, in Lindsay et al's research, there were eleven mild derangements of liver function tests and two moderate raised bilirubin in 57 patients. ${ }^{62}$ Meanwhile, Kim et al's study ${ }^{20}$ showed adverse events in 67 patients $(32.8 \%)$; specifically, hepatotoxicity $(n=39,19.1 \%)$ and nephrotoxicity $(n=8,3.9 \%)$ were common in this study and seven patients discontinued itraconazole therapy due to toxicity.

Table 4 Summary of meta-analysis for efficacy (with control arm)

\begin{tabular}{|c|c|c|c|c|c|}
\hline Cut-off value (mg/L) & $\operatorname{RR}(95 \% \mathrm{Cl})$ & $\begin{array}{l}\text { Number of } \\
\text { studies }\end{array}$ & $\begin{array}{l}\text { Number of } \\
\text { participants in } \\
\text { experimental } \\
\text { group }\end{array}$ & $\begin{array}{l}\text { Number of } \\
\text { participants } \\
\text { in control } \\
\text { group }\end{array}$ & $12 \%$ \\
\hline \multicolumn{6}{|l|}{ Rate of treatment success } \\
\hline$<0.25$ vs $\geq 0.25$ & $0.243(0.018,3.313)$ & 1 & 3 & 33 & NA \\
\hline$<0.5$ vs $\geq 0.5$ & $0.396(0.176,0.889)^{\mathrm{a}}$ & 2 & 18 & 29 & 0 \\
\hline$<1.0$ vs $\geq 1.0$ & $0.746(0.462,1.204)$ & 2 & 33 & 14 & 0 \\
\hline \multicolumn{6}{|l|}{ Incidence of IFI } \\
\hline$<0.25$ vs $\geq 0.25$ & $3.279(1.732,6.206)^{\mathrm{a}}$ & 6 & 149 & 419 & 0 \\
\hline$<0.5$ vs $\geq 0.5$ & $1.214(0.485,3.306)$ & 4 & 101 & 145 & 0 \\
\hline$<1.0$ vs $\geq 1.0$ & $0.203(0.026,2.034)$ & 2 & 20 & 7 & 0 \\
\hline
\end{tabular}

Note: aStatistically significant difference.

Abbreviations: $\mathrm{Cl}$, confidence interval; IFI, invasive fungal infection; NA, not applicable. 
Table 5 Summary of subgroup analysis for treatment success (without control arm)

\begin{tabular}{|c|c|c|c|c|c|c|}
\hline Subgroup & & $\begin{array}{l}\text { Cut-off value } \\
\text { (mg/L) }\end{array}$ & PR (95\% Cl) & $\begin{array}{l}\text { Number of } \\
\text { studies }\end{array}$ & $\begin{array}{l}\text { Number of } \\
\text { participants }\end{array}$ & $12 \%$ \\
\hline \multirow{6}{*}{$\begin{array}{l}\text { Combination } \\
\text { therapy }\end{array}$} & Yes & $<0.25$ & NA & NA & NA & NA \\
\hline & & $\geq 0.25$ & $0.605(0.439,0.770)$ & 2 & 32 & 0 \\
\hline & & $<0.5$ & $0.500(0.010,0.990)$ & 1 & 4 & NA \\
\hline & & $\geq 0.5$ & $0.682(0.356,1.008)$ & 2 & 28 & 73.57 \\
\hline & & $<1.0$ & $0.570(0.395,0.746)$ & 2 & 30 & 0 \\
\hline & & $\geq 1.0$ & $0.833(0.4 \mid 2,1.255)$ & I & 2 & NA \\
\hline \multirow{6}{*}{$\begin{array}{l}\text { Combination } \\
\text { therapy }\end{array}$} & No & $<0.25$ & $0.498(-0.204,1.200)$ & 2 & 22 & 93.32 \\
\hline & & $\geq 0.25$ & $0.493(0.332,0.653)$ & 4 & 122 & 71.41 \\
\hline & & $<0.5$ & $0.559(0.166,0.952)$ & 3 & 68 & 94.02 \\
\hline & & $\geq 0.5$ & $0.476(0.264,0.688)$ & 3 & 76 & 74.12 \\
\hline & & $<1.0$ & $0.654(0.427,0.88 \mathrm{I})$ & 3 & 78 & 81.13 \\
\hline & & $\geq 1.0$ & $0.414(0.277,0.550)$ & 3 & 66 & 23.57 \\
\hline \multirow[t]{7}{*}{ Study location } & Asian & $<0.25$ & $0.842(0.678,1.006)$ & I & 19 & NA \\
\hline & location & & & & & \\
\hline & & $\geq 0.25$ & $0.435(0.232,0.637)$ & I & 23 & NA \\
\hline & & $<0.5$ & $0.842(0.678,1.006)$ & I & 19 & NA \\
\hline & & $\geq 0.5$ & $0.435(0.232,0.637)$ & 1 & 23 & NA \\
\hline & & $<1.0$ & $0.842(0.678,1.006)$ & I & 19 & NA \\
\hline & & $\geq 1.0$ & $0.435(0.232,0.637)$ & 1 & 23 & NA \\
\hline \multirow[t]{7}{*}{ Study location } & Non-Asian & $<0.25$ & $0.125(-0.199,0.449)$ & I & 3 & NA \\
\hline & location & & & & & \\
\hline & & $\geq 0.25$ & $0.546(0.339,0.692)$ & 5 & $13 \mid$ & 67.21 \\
\hline & & $<0.5$ & $0.438(0.023,0.854)$ & 3 & 53 & 89.9 \\
\hline & & $\geq 0.5$ & $0.584(0.359,0.809)$ & 4 & 81 & 79.33 \\
\hline & & $<1.0$ & $0.572(0.437,0.706)$ & 4 & 89 & 40.23 \\
\hline & & $\geq 1.0$ & $0.531(0.249,0.812)$ & 3 & 45 & 68.29 \\
\hline
\end{tabular}

Abbreviations: $\mathrm{Cl}$, confidence interval; $\mathrm{NA}$, .

Table 6 Summary of subgroup analysis for prophylaxis failure (without control arm)

\begin{tabular}{|c|c|c|c|c|c|c|}
\hline Subgroup & & $\begin{array}{l}\text { Cut-off value } \\
\text { (mg/L) }\end{array}$ & PR (95\% Cl) & $\begin{array}{l}\text { Number } \\
\text { of studies }\end{array}$ & $\begin{array}{l}\text { Number of } \\
\text { participants }\end{array}$ & $12 \%$ \\
\hline \multirow[t]{6}{*}{ Study location } & Asian location & $<0.25$ & $0.053(-0.050,0.157)$ & 2 & 16 & 0 \\
\hline & & $\geq 0.25$ & $0.114(0.062,0.167)$ & 8 & 761 & 77.25 \\
\hline & & $<0.5$ & $0.174(0.016,0.332)$ & 3 & 60 & 65.78 \\
\hline & & $\geq 0.5$ & $0.097(0.043,0.150)$ & 5 & 701 & 80.87 \\
\hline & & $<1.0$ & $0.128(0.070,0.186)$ & 6 & 579 & 71.45 \\
\hline & & $\geq 1.0$ & $0.045(0.015,0.075)$ & 2 & 182 & 0 \\
\hline \multirow[t]{6}{*}{ Study location } & European location & $<0.25$ & $0.172(-0.012,0.356)$ & 3 & 112 & 92.61 \\
\hline & & $\geq 0.25$ & $0.037(0.010,0.065)$ & 7 & 639 & 78.45 \\
\hline & & $<0.5$ & $0.095(-0.071,0.260)$ & 2 & 76 & 81.2 \\
\hline & & $\geq 0.5$ & $0.056(0.013,0.099)$ & 7 & 394 & 79.96 \\
\hline & & $<1.0$ & $0.062(0.004,0.119)$ & 5 & 262 & 76.11 \\
\hline & & $\geq 1.0$ & $0.167(-0.132,0.465)$ & I & 6 & NA \\
\hline \multirow[t]{6}{*}{ Study location } & USA and Australia & $<0.25$ & $0.524(0.310,0.737)^{\mathrm{a}}$ & 1 & 21 & NA \\
\hline & & $\geq 0.25$ & $0.098(0.066,0.130)^{\mathrm{a}}$ & 4 & 326 & 0 \\
\hline & & $<0.5$ & $0.100(0.046,0.155)$ & 2 & 115 & 0 \\
\hline & & $\geq 0.5$ & $0.078(0.016,0141)$ & 3 & 222 & 62.95 \\
\hline & & $<1.0$ & $0.114(0.074,0.153)$ & 2 & 248 & 0 \\
\hline & & $\geq 1.0$ & $0.053(-0.005,0.111)$ & I & 57 & NA \\
\hline
\end{tabular}

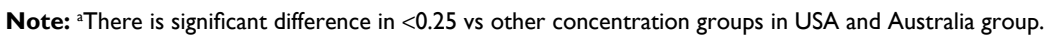
Abbreviations: $\mathrm{Cl}$, confidence interval; NA, . 
Table 7 Summary of subgroup analysis for prophylaxis failure (with control arm)

\begin{tabular}{|c|c|c|c|c|c|c|c|}
\hline $\begin{array}{l}\text { Cut-off value } \\
\text { (mg/L) }\end{array}$ & Subgroup & & $\operatorname{RR}(95 \% \mathrm{Cl})$ & $\begin{array}{l}\text { Number of } \\
\text { studies }\end{array}$ & $\begin{array}{l}\text { Number of } \\
\text { participants in } \\
\text { experimental } \\
\text { group }\end{array}$ & $\begin{array}{l}\text { Number of } \\
\text { participants in } \\
\text { control group }\end{array}$ & $12 \%$ \\
\hline \multirow[t]{3}{*}{$<0.25$ vs $\geq 0.25$} & Study location & Asian location & I.252 $(0.086,18.259)$ & 2 & 12 & 16 & 0 \\
\hline & & European location & $0.225(0.092,0.549)$ & 3 & 386 & 112 & 0 \\
\hline & & USA & $0.364(0.138,0.96 I)$ & I & 212 & 21 & NA \\
\hline \multirow[t]{3}{*}{$<0.5$ vs $\geq 0.5$} & Study location & Asian location & $0.750(0.017,32.676)$ & 1 & 7 & 5 & NA \\
\hline & & European location & $1.046(0.385,2.845)$ & 2 & 76 & 126 & 0 \\
\hline & & Australia & $5.526(0.309,98.923)$ & I & 18 & 14 & NA \\
\hline
\end{tabular}

Abbreviations: $\mathrm{Cl}$, confidence interval; NA, not applicable.

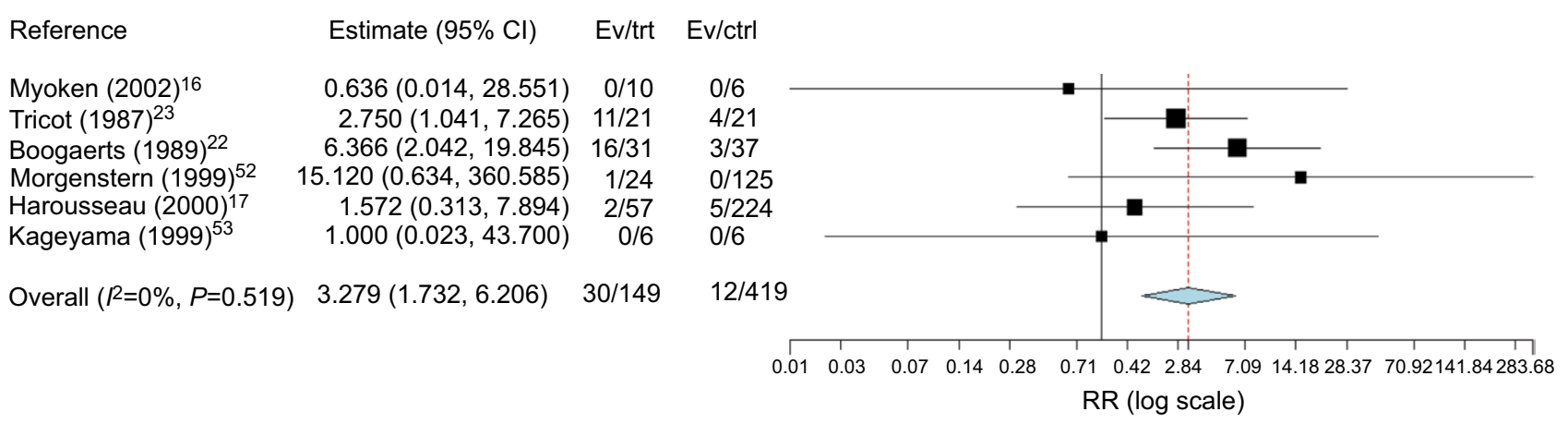

Figure 2 Meta-analysis for prophylaxis failure rate (trough concentration of $<0.25 \mathrm{mg} / \mathrm{L}$ comparison with $\geq 0.25 \mathrm{mg} / \mathrm{L}, \mathrm{RR}<\mathrm{I}$ favors $\mathrm{C}_{\text {trough }}<0.25 \mathrm{mg} / \mathrm{L}$ ).

Abbreviations: $\mathrm{Cl}$, confidence interval; ctrl, control group; Ev, events; trt, treatment group.

Reference

Cross et al $2000^{30}$

Subgroup $<0.25$ versus $>0.25\left(R^{2}=\mathrm{NA}, P=\mathrm{NA}\right)$

Cross et al $2000^{30}$

Lebeau et al $1994^{46}$

Subgroup $<0.5$ versus $>0.5(R=0 \%, P=0.229)$

Cross et al $2000^{30}$

Lebeau et al $1994^{46}$

Subgroup $<1.0$ versus $>1.0\left(R^{2}=0 \%, P=0.857\right)$

Overall $\left(I^{2}=0 \%, P=0.444\right)$

$\begin{array}{ccl}\text { Estimate }(95 \% \mathrm{Cl}) & \text { Ev/trt } & \text { Ev/ctrl } \\ & & \\ 0.243(0.018,3.313) & 0 / 3 & 17 / 33 \\ 0.243(0.018,3.313) & 0 / 3 & 17 / 33 \\ & & \\ 0.210(0.056,0.780) & 2 / 14 & 15 / 22 \\ 0.583(0.209,1.627) & 2 / 4 & 6 / 7 \\ 0.396(0.176,0.889) & 4 / 18 & 21 / 29 \\ & & \\ 0.714(0.364,0.400) & 10 / 24 & 7 / 12 \\ 0.780(0.395,1.540) & 6 / 9 & 2 / 2 \\ 0.746(0.462,1.204) & 16 / 33 & 9 / 14 \\ & & \\ 0.619(0.412,0.929) & 20 / 54 & 47 / 76\end{array}$

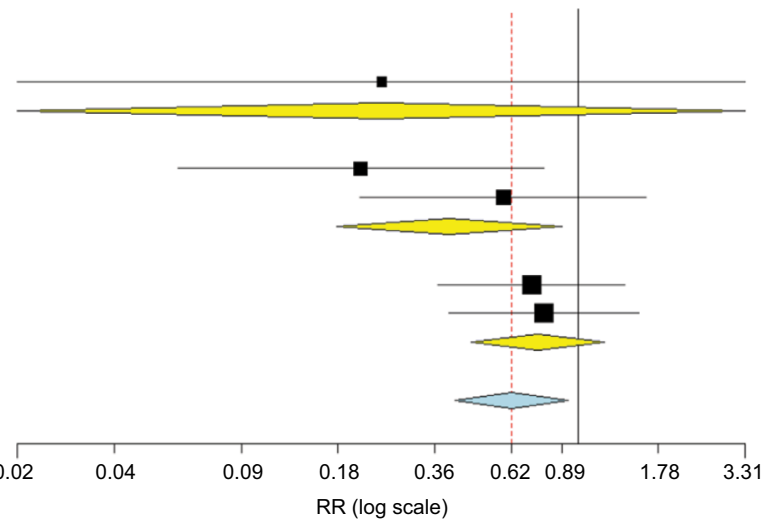

Figure 3 Meta-analysis for treatment success rate (trough concentration < cut-off value comparison with $\geq$ cut-off value, RR $<\mathrm{I}$ favors $\geq$ cut-off value). Abbreviations: $\mathrm{Cl}$, confidence interval; ctrl, control group; Ev, events; trt, treatment group.

Considering the myriad and prevalence of adverse effects in all these studies, an itraconazole trough level of $1.0 \mathrm{mg} / \mathrm{L}$ is associated with increased hepatotoxicity and other adverse events.

\section{Evaluation when using the bioassay method}

Due to the variation in measurements of blood itraconazole using bioassay (measures both itraconazole and hydroxy-itraconazole) vs HPLC (which measures itraconazole separately), it seems that concentrations measured by bioassay are 5-fold higher compared with HPLC/mass spectrometry. ${ }^{67}$ Few studies have incorporated bioassay, so we excluded these studies from our meta-analysis. Accordingly, we have not identified any recommendations on itraconazole trough level measured by bioassay.

For treatment, Tucker et al ${ }^{68}$ reported a trough concentration of $6.5 \pm 4.2 \mathrm{mg} / \mathrm{L}$ in 28 responders and $4.0 \pm 3.2 \mathrm{mg} / \mathrm{L}$ in eleven non-responders. Another, Sharkey et al's study, noted no elevations in hepatic enzyme values compared to baseline values in eight patients where two were $<2 \mathrm{mg} / \mathrm{L}$ and the other six were $>5 \mathrm{mg} / \mathrm{L} .{ }^{27}$ Galgiani et a ${ }^{69}$ found 61 responded to itraconazole treatment in 97 patients with $6-8 \mathrm{mg} / \mathrm{L}$ and two adverse events could have been caused by itraconazole including 
one case of elevated liver enzyme levels and one hypokalemia cased. Denning et al's study ${ }^{25}$ determined that trough levels $<2.5$ $\mathrm{mg} / \mathrm{L}$ in three responders and one non-responder, $2.5-5 \mathrm{mg} / \mathrm{L}$ in two responders and one non-responder, $5-10 \mathrm{mg} / \mathrm{L}$ in two responders; and finally $>10 \mathrm{mg} / \mathrm{L}$ in three responders.

For prophylaxis, according to Lestner et al's study, ${ }^{32}$ at $\mathrm{C}_{\text {trough }}<17.1 \mathrm{mg} / \mathrm{L}, 47(31 \%)$ patients developed itraconazolerelated toxicity; at $\mathrm{C}_{\text {trough }} \geq 17.1 \mathrm{mg} / \mathrm{L}, 55(86 \%)$ patients developed toxicity. Wheat et $\mathrm{al}^{70}$ reported that, in their study, 39 of 42 patients with $6.8 \mathrm{mg} / \mathrm{L}$ achieved successful suppression, but 37 patients ( $88 \%$ ) experienced grade 3 or 4 (severe or life-threatening) adverse events. One patient was removed from the trial entirely because of itraconazole. In addition, no patient receiving prophylaxis developed invasive aspergillosis and withdrew from the trial due to side effects, nor were toxicities attributed to rising cyclosporine levels associated with itraconazole (Patterson et al: $0.5 \mathrm{mg} / \mathrm{L}$, six patients; $3.5 \mathrm{mg} / \mathrm{L}$, six patients). ${ }^{71}$ Denning's study also exhibited that patients with serum concentrations of $8 \mathrm{mg} / \mathrm{L}$ tended to have better clinical outcomes when using itraconazole for primary treatment of invasive aspergillosis. ${ }^{72}$

\section{Quality assessment}

Using a 9-point scoring system, most studies we analyzed scored between 7 and 9. In a 6-point scoring system, most studies scored between 4 and 6 . The result showed that most studies did well in sample selection and comparability but failed in outcome due to short or inadequate follow-ups. Assessment of study-specific quality scores from the Newcastle-Ottawa Scale system is summarized in Table 8.

\section{Discussion}

As an antifungal agent, itraconazole has been widely used for the treatment of deep mycoses and prophylaxis of IFIs in patients with profound and prolonged neutropenia, bone marrow transplant recipients, solid organ transplant recipients, and other immunocompromised populations. Although many studies have analyzed itraconazole's efficacy compared with other antifungal drugs, researchers, so far, have drawn no definitive conclusions on the optimum trough concentration for treatment. Itraconazole exhibits high interand intra-patient variability in the pharmacokinetic profile following oral and intravenous doses, so TDM is suggested to optimize the efficacy and avoid toxicity. ${ }^{21}$ Considering the lower power of individual observational studies and clinical needs, we conducted this systematic review and meta-analysis to provide a more reliable and explicit recommendation on the optimum trough concentration of itraconazole, with less random errors and more precise estimates.
To our knowledge, this is the first meta-analysis focusing on the relationship between itraconazole trough level and the efficacy/safety. After pooling available data from 29 included articles, the meta-analysis revealed that an itraconazole trough concentration of $0.25 \mathrm{mg} / \mathrm{L}$ is associated with successful prophylaxis of IFI. This conclusion differs from the $0.5-1.0 \mathrm{mg} / \mathrm{L}$ threshold that some publications have suggested, likely due to their limited study subjects. ${ }^{73,74} \mathrm{We}$ conducted a subgroup analysis by study location, thereby demonstrating that the rate of prophylaxis failure significantly increased at a cut-off level of $<0.25 \mathrm{mg} / \mathrm{L}$ in USA + Australia subgroup patients compared with other concentration regimens. However, subgroup analysis results of the Asia and Europe subgroup were different and insignificant, suggesting a possibility that the concentration-efficacy relationship follows a different profile among different ethnicities. We recognize that the study number was limited and sample size was small in our meta-analysis, therefore further studies are needed to verify the differences in different ethnicities.

Our meta-analysis also demonstrated that a target value of $0.5 \mathrm{mg} / \mathrm{L}$ increased treatment success. It is similar to the guideline which recommends itraconazole trough concentration of $0.5-1.0 \mathrm{mg} / \mathrm{L}$ as it pertains to treatment of IFIs. ${ }^{21}$ We divided our subgroups into combination therapy and study location. First, itraconazole inhibits CYP3A4, which leads to a number of clinically relevant drug-drug interactions. Combination therapy with amphotericin B or other drugs may change the profile of drug exposure, ${ }^{14,75}$ which might explain why the combination therapy subgroup did not show significance at the $0.5 \mathrm{mg} / \mathrm{L}$ cut-off level. Second, each cut-off value of Asian location subgroup differed significantly. As there is only one study in every concentration group, we regard these subgroup analysis results as likely to be unreliable. Notably, the small number and size of included studies for treatment success limits the utility of this metric. ${ }^{30,46}$

During our meta-analysis, we observed heterogeneity in the results, some of which persisted even in subgroup analysis by combination therapy and study location. Nevertheless, sensitivity analysis resulted in a dramatic decrease in $I^{2}$ through removing method (Table S1 and S2). These results revealed that sample size and the criteria used for assessment could be the sources of heterogeneity. It is also possible that differences in disease, itraconazole dose, age and/or duration of disease or follow-up may be responsible for the heterogeneity we observed. Hence, future studies are needed to explore further causalities. However, though $I^{2}$ decreased, the $95 \%$ CI of each cut-off value only changed insignificantly, indicating the robustness. 
Table 8 Quality of studies included in the meta-analysis

\begin{tabular}{|c|c|c|c|c|c|c|c|c|c|}
\hline \multirow[t]{3}{*}{ Study } & \multicolumn{8}{|c|}{ Newcastle-Ottawa Quality Assessment Scale (cohort study) } & \multirow[t]{3}{*}{ Score } \\
\hline & \multicolumn{4}{|c|}{ Selection } & \multirow{2}{*}{$\begin{array}{l}\text { Comparability } \\
\text { Q5 }\end{array}$} & \multicolumn{3}{|c|}{ Outcome } & \\
\hline & $\overline{Q I}$ & Q2 & Q3 & Q4 & & Q6 & Q7 & Q8 & \\
\hline \multicolumn{10}{|l|}{ Studies with control } \\
\hline Cross et al $2000^{30}$ & 约 & is & 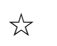 & 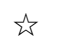 & 论柁 & is & - & - & 7 \\
\hline Lebeau et al $1994^{46}$ & ts & is & 幽 & is & 论论 & is & is & $i$ & 9 \\
\hline Myoken et al $2002^{16}$ & 拧 & is & 拧 & is & - & 论 & is & $i$ & 7 \\
\hline Tricot et al $1987^{23}$ & 拧 & is & 拧 & is & 论论 & 论 & - & - & 7 \\
\hline Boogaerts et al $1989^{22}$ & 约 & 岤 & 约 & 拧 & $\sum-$ & is & - & - & 6 \\
\hline Morgenstern et al $1999^{52}$ & th & 柁 & 功 & ț & 论柁 & 论 & 计 & $i$ & 9 \\
\hline Harousseau et al $2000^{17}$ & ts & 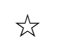 & 论 & ts & 论论 & ts & - & - & 7 \\
\hline Kageyama et al $1999^{53}$ & th & $i$ & ts & ts & 计证 & ts & - & - & 7 \\
\hline Brett et al $2013^{18}$ & 拧 & is & ț & is & 论柁 & $i$ & - & - & 7 \\
\hline Ceesay et al $2016^{19}$ & 论 & 拧 & $\hat{s}$ & is & 论柁 & $i$ & - & - & 7 \\
\hline Schmitt et al $200 I^{54}$ & $i$ & is & ț & is & 论论 & is & - & - & 7 \\
\hline \multicolumn{10}{|l|}{ Studies without control } \\
\hline Havu et al 199947 & 拧 & l & 论 & is & l & is & 论 & 拧 & 6 \\
\hline Matsumoto et al $1999^{48}$ & ts & l & 论 & ts & l & ts & 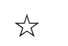 & ț & 6 \\
\hline Caillot $2003^{49}$ & is & l & $\hat{s}$ & is & l & 论 & is & 岤 & 6 \\
\hline Yoshida et al $2012^{50}$ & 拧 & l & ț & is & l & $i$ & is & $i$ & 6 \\
\hline Caillot et al $2001^{51}$ & 幽 & l & $\hat{s}$ & is & l & it & - & - & 4 \\
\hline Kanda et al $1998^{55}$ & 拧 & l & ț & is & l & $i$ & - & - & 4 \\
\hline Glasmacher et al $1999^{24}$ & 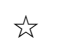 & l & $\hat{z}$ & is & l & is & - & - & 4 \\
\hline Simon et al $200^{75} 6$ & 功 & l & 功 & is & l & is & - & - & 4 \\
\hline Marr et al $2004^{57}$ & 功 & l & 论 & is & l & 论 & 功 & 岤 & 6 \\
\hline Boogaerts et al $2001^{58}$ & 功 & l & 功 & is & l & ts & - & - & 4 \\
\hline Winston et al $2002^{59}$ & ts & l & 幽 & th & l & $i$ & 拧 & ț & 6 \\
\hline Glasmacher et al $199^{86} 0$ & 拧 & l & 幽 & 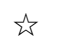 & l & $i$ & - & - & 4 \\
\hline Lin et al $2014^{61}$ & 拧 & l & ț & is & l & $i$ & is & $i$ & 6 \\
\hline Kim et al $2014^{20}$ & ts & l & 幽 & is & l & is & - & - & 4 \\
\hline Lindsay et al $2017^{62}$ & 拧 & l & 功 & is & l & 论 & 拧 & 论 & 6 \\
\hline Liu et al $2015^{64}$ & 弥 & l & 㶦 & 拧 & l & 糸 & - & - & 4 \\
\hline Toubai et al $2005^{63}$ & 约 & l & 㶦 & 拧 & l & 约 & 约 & is & 6 \\
\hline Liu et al $2013^{64}$ & 统 & I & 拧 & ts & I & 弥 & - & - & 4 \\
\hline
\end{tabular}

Notes: The data is presented using the Newcastle-Ottawa Quality Assessment Scale, " $\downarrow$ ”, represents the score; “-” the item(question) has no score; “””, not applicable. Q1: the exposed cohort was truly or somewhat representative? Q2: the non-exposed cohort was drawn from the same community as the exposed cohort? Q3: exposure was ascertained by secure record or structured interview? Q4: outcome of interest was not present at start of study? Q5: on the basis of the design or analysis, cohorts had comparability? (controls for the most important factor? controls for any additional factor?) Q6: outcome was independent blind assessment or record linkage? Q7: follow-up was long enough for outcomes to occur? Q8: follow-up of cohorts was adequate? A study can be awarded a maximum of one star for each numbered item within the selection and outcome categories. A maximum of two stars can be given for comparability.

Abbreviation: Q, question.

There are too little study-contributed data for IFI-related mortality for us to have effectively pooled data in our review. ${ }^{60}$ The clinical outcomes and definitions of safety in studies were various, wherein some studies reported adverse events grade 3 or $4{ }^{66}$ some reported liver function disorders with different criteria, ${ }^{46,50}$ some reported adverse reactions related to itraconazole treatment, ${ }^{51,60}$ and various trials reported the adverse events and abnormal laboratory examination values without consistent standards. ${ }^{17,48,58}$ Thus we could not combine results to forge a comprehensive meta-analysis. Most patients treated with itraconazole are already immunocompromised and undergoing chemotherapy, which each involves conditions with many adverse effects. The relationship between treatment and adverse events remains unclear, and most guidelines indicate an increased incidence of toxicity at higher itraconazole concentrations without explicitly recommending an optimum trough concentration for safety. ${ }^{21,73}$ After reviewing many studies, we offer $1.0 \mathrm{mg} / \mathrm{L}$ as the cut-off value that is associated with increased hepatotoxicity and other adverse events. To fully elucidate this issue, further studies are needed.

Our meta-analysis and review has the following strengths. First, it is the first to focus on the relationship of itraconazole trough concentration with efficacy and safety, providing certain reference significance to clinical practice. Second, our meta-analysis compared commonly used cut-off levels in a single analysis for individual cut-off levels. Finally, we included Japanese articles in this meta-analysis to maximize the reliability considering the prevalence of the research in 
Japan, while most English language reviews have not done this until now.

We acknowledge the following limitations to our work. First, the number of studies and sample sizes were relatively small, leading to potentially insufficient power to detect mild differences. Second, we were unable to perform subgroup analysis for the pediatric population because we only identified two studies designed for children. Besides, we could not analyze the influences of different pathogen and infection locations on the results. Third, the use of observational studies in a meta-analysis is prone to biases and confounding factors inherent in the original studies. Finally, although our subgroup analysis and sensitivity analyses explained some heterogeneity in the results, there is a clear need for further study.

\section{Conclusion}

In conclusion, our meta-analysis of published studies demonstrates that $0.25 \mathrm{mg} / \mathrm{L}$ is the lower threshold of the target itraconazole trough concentration during prophylaxis of fungal infections. Additionally, the target $0.5 \mathrm{mg} / \mathrm{L}$ is the lower limit for successful treatment. We have deduced that a trough level of $1.0 \mathrm{mg} / \mathrm{L}$ is associated with substantially increased hepatotoxicity and other adverse events (using HPLC).

\section{Acknowledgment}

This work was supported by the National Science and Technology Major Project "Creation of major new drugs" (number 2017ZX09304029).

\section{Disclosure}

The authors report no conflicts of interest in this work.

\section{References}

1. Chamilos G, Luna M, Lewis RE, et al. Invasive fungal infections in patients with hematologic malignancies in a tertiary care cancer center: an autopsy study over a 15-year period (1989-2003). Haematologica. 2006;91(7):986-989.

2. Slobbe L, Polinder S, Doorduijn JK, et al. Outcome and medical costs of patients with invasive aspergillosis and acute myelogenous leukemiamyelodysplastic syndrome treated with intensive chemotherapy: an observational study. Clin Infect Dis. 2008;47(12):1507-1512.

3. Neofytos D, Horn D, Anaissie E, et al. Epidemiology and outcome of invasive fungal infection in adult hematopoietic stem cell transplant recipients: analysis of Multicenter Prospective Antifungal Therapy (PATH) Alliance registry. Clin Infect Dis. 2009;48(3):265-273.

4. Slain D, Rogers PD, Cleary JD, Chapman SW. Intravenous itraconazole. Ann Pharmacother. 2001;35(6):720-729.

5. Ullmann AJ, Akova M, Herbrecht R, et al. ESCMID* guideline for the diagnosis and management of Candida diseases 2012: adults with haematological malignancies and after haematopoietic stem cell transplantation (HCT). Clin Microbiol Infect. 2012;18 Suppl 7:53-67.

6. Lortholary O, Petrikkos G, Akova M, et al. ESCMID* guideline for the diagnosis and management of Candida diseases 2012: patients with HIV infection or AIDS. Clin Microbiol Infect. 2012;18 Suppl 7:68-77.
7. Hope WW, Castagnola E, Groll AH, et al. ESCMID* guideline for the diagnosis and management of Candida diseases 2012: prevention and management of invasive infections in neonates and children caused by Candida spp. Clin Microbiol Infect. 2012;18 Suppl 7:38-52.

8. Walsh TJ, Anaissie EJ, Denning DW, et al. Treatment of aspergillosis: clinical practice guidelines of the Infectious Diseases Society of America. Clin Infect Dis. 2008;46(3):327-360.

9. Limper AH, Knox KS, Sarosi GA, et al. An official American Thoracic Society statement: Treatment of fungal infections in adult pulmonary and critical care patients. Am J Respir Crit Care Med. 2011;183(1): 96-128.

10. Pappas PG, Kauffman CA, Andes DR, et al. Clinical Practice Guideline for the Management of Candidiasis: 2016 Update by the Infectious Diseases Society of America. Clin Infect Dis. 2016;62(4):409-417.

11. Patterson TF, Thompson GR, Denning DW, et al. Practice Guidelines for the Diagnosis and Management of Aspergillosis: 2016 Update by the Infectious Diseases Society of America. Clin Infect Dis. 2016;63(4):e1-e60.

12. Maertens J, Marchetti O, Herbrecht R, et al. European guidelines for antifungal management in leukemia and hematopoietic stem cell transplant recipients: summary of the ECIL 3--2009 update. Bone Marrow Transplant. 2011;46(5):709-718.

13. Allegra S, Fatiguso G, de Francia S, et al. Pharmacokinetic evaluation of oral itraconazole for antifungal prophylaxis in children. Clin Exp Pharmacol Physiol. 2017;44(11):1083-1088.

14. Morgan J, Wannemuehler KA, Marr KA, et al. Incidence of invasive aspergillosis following hematopoietic stem cell and solid organ transplantation: interim results of a prospective multicenter surveillance program. Med Mycol. 2005;43 Suppl 1:49-58.

15. Yamagishi Y, Hamada Y, Hagihara M, Mikamo H. Population pharmacokinetics of itraconazole in Japanese patients with invasive fungal peritonitis. Jpn J Antibiot. 2013;66(3):159-168.

16. Myoken Y, Sugata T, Kyo T, Fujihara M, Mikami Y. Itraconazole prophylaxis for invasive gingival aspergillosis in neutropenic patients with acute leukemia. J Periodontol. 2002;73(1):33-38.

17. Harousseau JL, Dekker AW, Stamatoullas-Bastard A, et al. Itraconazole oral solution for primary prophylaxis of fungal infections in patients with hematological malignancy and profound neutropenia: a randomized, double-blind, double-placebo, multicenter trial comparing itraconazole and amphotericin B. Antimicrob Agents Chemother. 2000;44(7):1887-1893.

18. Brett J, Chong O, Graham GG, et al. Antifungal use and therapeutic monitoring of plasma concentrations of itraconazole in heart and lung transplantation patients. Ther Drug Monit. 2013;35(1):133-136.

19. Ceesay MM, Couchman L, Smith M, Wade J, Flanagan RJ, Pagliuca A. Triazole antifungals used for prophylaxis and treatment of invasive fungal disease in adult haematology patients: Trough serum concentrations in relation to outcome. Med Mycol. 2016;54(7):691-698.

20. Kim JS, Cheong JW, Kim YK, et al. The relationship between the success rate of empirical antifungal therapy with intravenous itraconazole and clinical parameters, including plasma levels of itraconazole, in immunocompromised patients receiving itraconazole oral solution as prophylaxis: a multicenter, prospective, open-label, observational study in Korea. Ann Hematol. 2014;93(1):33-42.

21. Ashbee HR, Barnes RA, Johnson EM, Richardson MD, Gorton R, Hope WW. Therapeutic drug monitoring (TDM) of antifungal agents: guidelines from the British Society for Medical Mycology. J Antimicrob Chemother. 2014;69(5):1162-1176.

22. Boogaerts MA, Verhoef GE, Zachee P, Demuynck H, Verbist L, de Beule $\mathrm{K}$. Antifungal prophylaxis with itraconazole in prolonged neutropenia: correlation with plasma levels. Mycoses. 1989;32 Suppl 1:103-108.

23. Tricot G, Joosten E, Boogaerts MA, Vande Pitte J, Cauwenbergh G. Ketoconazole vs. itraconazole for antifungal prophylaxis in patients with severe granulocytopenia: preliminary results of two nonrandomized studies. Rev Infect Dis. 1987;9 Suppl 1:S94-99.

24. Glasmacher A, Hahn C, Leutner C, et al. Breakthrough invasive fungal infections in neutropenic patients after prophylaxis with itraconazole. Mycoses. 1999;42(7-8):443-451. 
25. Denning DW, Tucker RM, Hanson LH, Stevens DA. Treatment of invasive aspergillosis with itraconazole. Am J Med. 1989;86(6 Pt 2):791-800.

26. Denning DW, Tucker RM, Hanson LH, Hamilton JR, Stevens DA. Itraconazole therapy for cryptococcal meningitis and cryptococcosis. Arch Intern Med. 1989;149(10):2301-2308.

27. Sharkey PK, Rinaldi MG, Dunn JF, Hardin TC, Fetchick RJ, Graybill JR. High-dose itraconazole in the treatment of severe mycoses. Antimicrob Agents Chemother. 1991;35(4):707-713.

28. Wheat J, Hafner R, Korzun AH, et al. Itraconazole treatment of disseminated histoplasmosis in patients with the acquired immunodeficiency syndrome. AIDS Clinical Trial Group. Am J Med. 1995;98(4):336-342.

29. Cartledge JD, Midgely J, Gazzard BG. Itraconazole solution: higher serum drug concentrations and better clinical response rates than the capsule formulation in acquired immunodeficiency syndrome patients with candidosis. J Clin Pathol. 1997;50(6):477-480.

30. Cross LJ, Bagg J, Oliver D, Warnock D. Serum itraconazole concentrations and clinical responses in Candida-associated denture stomatitis patients treated with itraconazole solution and itraconazole capsules. J Antimicrob Chemother. 2000;45(1):95-99.

31. Glasmacher A, Prentice A, Gorschlüter M, et al. Itraconazole prevents invasive fungal infections in neutropenic patients treated for hematologic malignancies: evidence from a meta-analysis of 3,597 patients. J Clin Oncol. 2003;21(24):4615-4626.

32. Lestner JM, Roberts SA, Moore CB, Howard SJ, Denning DW, Hope WW. Toxicodynamics of itraconazole: implications for therapeutic drug monitoring. Clin Infect Dis. 2009;49(6):928-930.

33. Lestner JM, Denning DW. Tremor: a newly described adverse event with long-term itraconazole therapy. J Neurol Neurosurg Psychiatry. 2010;81(3):327-329.

34. Vardakas KZ, Michalopoulos A, Falagas ME. Fluconazole versus itraconazole for antifungal prophylaxis in neutropenic patients with haematological malignancies: a meta-analysis of randomised-controlled trials. Br J Haematol. 2005;131(1):22-28.

35. Wang J, Zhan P, Zhou R, et al. Prophylaxis with itraconazole is more effective than prophylaxis with fluconazole in neutropenic patients with hematological malignancies: a meta-analysis of randomized-controlled trials. Med Oncol. 2010;27(4):1082-1088.

36. Stroup DF, Berlin JA, Morton SC, et al. Meta-analysis of observational studies in epidemiology: a proposal for reporting. Meta-analysis Of Observational Studies in Epidemiology (MOOSE) group. JAMA. 2000;283(15):2008-2012.

37. Shokohi T, Badali H, Amirrajab N, Ataollahi MR, Kouhpayeh SA, Afsarian MH. In vitro activity of five antifungal agents against Candida albicans isolates, Sari, Iran. Curr Med Mycol. 2016;2(2):34-39.

38. Pfaller MA, Diekema DJ, Messer SA, Hollis RJ, Jones RN. In vitro activities of caspofungin compared with those of fluconazole and itraconazole against 3,959 clinical isolates of Candida spp., including 157 fluconazole-resistant isolates. Antimicrob Agents Chemother. 2003;47(3):1068-1071.

39. Sabatelli F, Patel R, Mann PA, et al. In vitro activities of posaconazole, fluconazole, itraconazole, voriconazole, and amphotericin B against a large collection of clinically important molds and yeasts. Antimicrob Agents Chemother. 2006;50(6):2009-2015.

40. Wheat LJ, Freifeld AG, Kleiman MB, et al. Clinical practice guidelines for the management of patients with histoplasmosis: 2007 update by the Infectious Diseases Society of America. Clin Infect Dis. 2007;45(7):807-825.

41. Hardin TC, Graybill JR, Fetchick R, Woestenborghs R, Rinaldi MG, Kuhn JG. Pharmacokinetics of itraconazole following oral administration to normal volunteers. Antimicrob Agents Chemother. 1988;32(9):1310-1313.

42. Smith D, van de Velde V, Woestenborghs R, Gazzard BG. The pharmacokinetics of oral itraconazole in AIDS patients. J Pharm Pharmacol. 1992;44(7):618-619.

43. Wells GA, Shea BJ, O'Connell D, et al. The Newcastle-Ottawa Scale (NOS) for Assessing the Quality of Non-Randomized Studies in MetaAnalysis. Appl Eng Agric. 2014;18:727-734.
44. Lopez-Olivo MA, Pratt G, Palla SL, Salahudeen A. Rasburicase in tumor lysis syndrome of the adult: a systematic review and meta-analysis. $\mathrm{Am}$ J Kidney Dis. 2013;62(3):481-492.

45. Deeks JJ, Higgins JP, Altman DG. Analysing data and undertaking meta-analyses. In: Higgins JP, Green S, editors. Cochrane Handbook for Systematic Reviews of Interventions Version 5.1.0. The Cochrane Collaboration; 2011.

46. Lebeau B, Pelloux H, Pinel C, et al. Itraconazole in the treatment of aspergillosis: a study of 16 cases. Mycoses. 1994;37(5-6):171-179.

47. Havu V, Brandt $\mathrm{H}$, Heikkilä $\mathrm{H}$, et al. Continuous and intermittent itraconazole dosing schedules for the treatment of onychomycosis: a pharmacokinetic comparison. Br J Dermatol. 1999;140(1):96-101.

48. Matsumoto T, Tanuma H, Nishiyama S. Clinical and pharmacokinetic investigations of oral intraconazole in the treatment of onychomycosis. Mycoses. 1999;42(1-2):79-91.

49. Caillot D. Intravenous itraconazole followed by oral itraconazole for the treatment of amphotericin-B-refractory invasive pulmonary aspergillosis. Acta Haematol. 2003;109(3):111-118.

50. Yoshida K, Kurashima A, Kamei K, et al. Efficacy and safety of short- and long-term treatment of itraconazole on chronic necrotizing pulmonary aspergillosis in multicenter study. JInfect Chemother. 2012;18(3):378-385.

51. Caillot D, Bassaris H, Mcgeer A, et al. Intravenous itraconazole followed by oral itraconazole in the treatment of invasive pulmonary aspergillosis in patients with hematologic malignancies, chronic granulomatous disease, or AIDS. Clin Infect Dis. 2001;33(8):e83-e90.

52. Morgenstern GR, Prentice AG, Prentice HG, Ropner JE, Schey SA, Warnock DW. A randomized controlled trial of itraconazole versus fluconazole for the prevention of fungal infections in patients with haematological malignancies. U.K. Multicentre Antifungal Prophylaxis Study Group. Br J Haematol. 1999;105(4):901-911.

53. Kageyama S, Masuya M, Tanaka I, et al. Plasma concentration of itraconazole and its antifungal prophylactic efficacy in patients with neutropenia after chemotherapy for acute leukemia. J Infect Chemother. 1999;5(4):213-216.

54. Schmitt C, Perel Y, Harousseau JL, et al. Pharmacokinetics of itraconazole oral solution in neutropenic children during long-term prophylaxis. Antimicrob Agents Chemother. 2001;45(5):1561-1564.

55. Kanda Y, Kami M, Matsuyama T, et al. Plasma concentration of itraconazole in patients receiving chemotherapy for hematological malignancies: the effect of famotidine on the absorption of itraconazole. Hematol Oncol. 1998;16(1):33-37.

56. Simon A, Besuden M, Vezmar S, et al. Itraconazole prophylaxis in pediatric cancer patients receiving conventional chemotherapy or autologous stem cell transplants. Support Care Cancer. 2007;15(2):213-220.

57. Marr KA, Crippa F, Leisenring W, et al. Itraconazole versus fluconazole for prevention of fungal infections in patients receiving allogeneic stem cell transplants. Blood. 2004;103(4):1527-1533.

58. Boogaerts MA, Maertens J, van der Geest R, et al. Pharmacokinetics and safety of a 7-day administration of intravenous itraconazole followed by a 14-day administration of itraconazole oral solution in patients with hematologic malignancy. Antimicrob Agents Chemother. 2001;45(3):981-985.

59. Winston DJ, Busuttil RW. Randomized controlled trial of oral itraconazole solution versus intravenous/oral fluconazole for prevention of fungal infections in liver transplant recipients. Transplantation. 2002;74(5):688-695.

60. Glasmacher A, Molitor E, Hahn C, et al. Antifungal prophylaxis with itraconazole in neutropenic patients with acute leukaemia. Leukemia. 1998;12(9):1338-1343.

61. Lin R, Xu X, LiY, et al. Comparison of long-term and short-term administration of itraconazole for primary antifungal prophylaxis in recipients of allogeneic hematopoietic stem cell transplantation: a multicenter, randomized, open-label trial. Transpl Infect Dis. 2014;16(2):286-294.

62. Lindsay J, Sandaradura I, Wong K, et al. Serum levels, safety and tolerability of new formulation SUBA-itraconazole prophylaxis in patients with haematological malignancy or undergoing allogeneic stem cell transplantation. J Antimicrob Chemother. 2017;72(12):3414-3419.

63. Toubai T, Tanaka J, Ota S, et al. Itraconazole capsules as antifungal prophylaxis for neutropenic patients with hematological malignancies from a single institution. Jpn J Antibiot. 2005;58(6):507. 
64. Liu X, Huang Y, Yang DL, et al. Prophylaxis of invasive fungal infection with different administration regimens of itraconazole in patients with acute myeloid leukemia: a report from a randomized, controlled trial. Chin J Hematol. 2013;34:502.

65. Liu WX. Clinical Research on Ltraconazole in Prevention of Pulmonary Invasive Fungal Infection (IFI) in Patients with Hemopathy. Journal of Aerospace Medicine. 2015;26:1318-1320. Available from: http://kns. cnki.net/KCMS/detail/detail.aspx?dbcode $=$ CJFQ\&dbname $=$ CJFDLA ST2015\&filename $=$ HKHT201511002\&v $=$ MTUyMjJDVVJMS2ZZT 2RvRkNqblVyL05MU2JEZXJHNEg5VE5ybzlGWm9SOGVYMUx1eFITN0RoMVQzcVRyV00xRnI=.

66. Indiana University. A Pilot Trial of Itraconazole Pharmacokinetics in Patients With Metastatic Breast Cancer. Available from: https:// clinicaltrials.gov/ct2/show/results/NCT00798135. NLM identifier: NCT00798135. Accessed June 22, 2018.

67. Law D, Moore CB, Denning DW. Bioassay for serum itraconazole concentrations using hydroxyitraconazole standards. Antimicrob Agents Chemother. 1994;38(7):1561-1566.

68. Tucker RM, Denning DW, Arathoon EG, Rinaldi MG, Stevens DA. Itraconazole therapy for nonmeningeal coccidioidomycosis: Clinical and laboratory observations. J Am Acad Dermatol. 1990;23(3):593-601.
69. Galgiani JN, Catanzaro A, Cloud GA, et al. Comparison of oral fluconazole and itraconazole for progressive, nonmeningeal coccidioidomycosis. A randomized, double-blind trial. Mycoses Study Group. Ann Intern Med. 2000;133:676-686.

70. Wheat J, Hafner R, Wulfsohn M, et al. Prevention of relapse of histoplasmosis with itraconazole in patients with the acquired immunodeficiency syndrome. Ann Intern Med. 1993;118(8):610-616.

71. Patterson TF, Peters J, Levine SM, et al. Systemic availability of itraconazole in lung transplantation. Antimicrob Agents Chemother. 1996;40: 2217-2220.

72. Denning DW. Treatment of invasive aspergillosis.JInfect. 1994;28(Suppl 1): 25-33.

73. Goodwin ML, Drew RH. Antifungal serum concentration monitoring: an update. J Antimicrob Chemother. 2008;61(1):17-25.

74. Andes D, Pascual A, Marchetti O. Antifungal Therapeutic Drug Monitoring: Established and Emerging Indications. Antimicrob Agents Chemother. 2009;53(1):24-34.

75. Isoherranen N, Kunze KL, Allen KE, Nelson WL, Thummel KE. Role of itraconazole metabolites in CYP3A4 inhibition. Drug Metab Dispos. 2004;32(10):1121-1131.
Infection and Drug Resistance

\section{Publish your work in this journal}

Infection and Drug Resistance is an international, peer-reviewed openaccess journal that focuses on the optimal treatment of infection (bacterial, fungal and viral) and the development and institution of preventive strategies to minimize the development and spread of resistance. The journal is specifically concerned with the epidemiology of antibiotic

\section{Dovepress}

resistance and the mechanisms of resistance development and diffusion in both hospitals and the community. The manuscript management system is completely online and includes a very quick and fair peerreview system, which is all easy to use. Visit http://www.dovepress.com/ testimonials.php to read real quotes from published authors. 